\title{
0 Castigo Abstrato e o Castigo Concreto: eficácia da estrutura da crueldade institucional pela ausência do direito
}

\author{
The Abstract Punishment and the Concrete Punishment: effectiveness of the \\ structure of the institutional cruelty for the absence of the right
}

\author{
Vanessa Alexsandra de Melo Pedroso ${ }^{1}$ \\ Carlos Jair de Oliveira Jardim ${ }^{1}$ \\ ${ }^{1}$ Universidade Católica de Pernambuco, Recife, PE, Brasil
}

\begin{abstract}
Resumo: Este artigo analisa a função da pena privativa de liberdade e o seu real cumprimento no cárcere contemporâneo brasileiro. A metodologia utilizada neste trabalho baseia-se na análise qualitativa, empregando-se o método hipotético-dedutivo e dialético de análise histórico-lógica por meio de fontes documentais primárias e da revisão de literatura brasileira. Desse modo, os autores demonstram como a ausência do Direito pode gerar um sistema cruel que potencializa a punição dos cidadãos encarcerados, eis que, ao que tudo indica, o cárcere não se apresenta na atualidade como um instrumento social mais adequado para a recuperação da autoconsciência do transgressor.
\end{abstract}

Palavras-chave: Pena Privativa de Liberdade. Cárcere. Retributividade.
Abstract: This article aims to analyze the role of prison sentences and his real execution in the Brazilian jail. The methodology used in this study is based on qualitative analysis, reason why the hypothetical-deductive and dialectical method of historical-logical analysis, by means of primary documentary sources and the review of Brazilian literature. In this way, the authors demonstrate how the absence of the law can generate a cruel system that potentiates the punishment of the imprisoned citizens, since it seems that the jail does not present itself at present as a social instrument more adequate to the recovery of the self-consciousness of the transgressor.

Keywords: Prison Sentences. Jail. Retributivity.

Recebido em: 03/01/2019

Revisado em: 20/04/2019

Aprovado em: 25/05/2019 


\section{Introdução}

Essa análise escora sua fundamentação no fato de que o sistema prisional, em grande parte do mundo contemporâneo, perpassa pelo agonizante momento de crise. Pontualmente, no que diz respeito ao Brasil, essa crise deita raízes em diversas causas que potencializam o agravamento de situações, como: ausência de ordem nos presídios, a exemplo da superpopulação carcerária; da inexistência de tratamento adequado à recuperação do preso; da inadequação das penas aos delitos, dentre outras.

Nesse sentido, as consequências negativas assumem proporções deveras preocupantes aos diversos segmentos da sociedade. O cenário projetado - que já faz parte do imaginário coletivo - vem se tornando, de forma lenta e gradual, uma "chaga" da humanidade, cujo esquecimento e/ ou inércia, relativamente às propostas de solução, somente tende a perpetuar a situação de extremo desconforto social que se estende para além da população carcerária, já confinada nos presídios, e que golpeia de forma sistemática todo o restante da sociedade.

Note-se que o crescimento das rebeliões toma a cena do cotidiano das pessoas e protagonizam, na maioria das vezes, a tônica de espetaculares apresentações midiáticas nos meios informacionais. Não menos nocivo para a realidade caótica do sistema, alguns dos veículos de comunicação, no exercício de suas funções, revelam-se destituídos de verdadeiro preparo no trato do rigor que a questão merece, conduzindo à banalização e/ou desvirtuamento da análise do tema.

Esses movimentos de rebeldia que ocorrem nos estabelecimentos prisionais demonstram para a sociedade que eles são detentores de uma "teia" de perfis que conjugam simultaneamente o alto grau de periculosidade e sofisticação no seu plano organizacional. À guisa de demonstração dessas características, tem-se observado a elaboração de pleitos nas suas pautas de reivindicação referindo-se a necessidade de planejamento estatal para a inserção incondicional de instrumentos de implementação das mínimas condições de humanização no tratamento destinado aos aprisionados. 
É também na esteira desses acontecimentos que se observa, no âmbito jurídico, que a consciência pública desse desrespeito reverberou tamanha notoriedade que inclinou a jurisprudência a não punir o preso pelo artigo 354, do Código Penal, cuja tipificação refere-se ao motim de presos. Para tanto, as decisões judiciais se apoiaram no fundamento de que, em geral, os presos que se amotinam estão reivindicando direitos que lhe são inerentes e que, por sua vez, não estão sendo garantidos pelo Estado e, ainda que estivessem objetivando a mera fuga, essa não é punida pelo Código penal (GAYA, 2017).

Noutro viés dialético, a saudável inserção de temas como o sistema prisional, trazido aos espaços públicos de discussão, conseguiu descortinar que o subjacente propósito da "luta pela melhoria" traz no bojo de sua complexidade a intenção de apropriação do controle do comando dos presídios.

Em que pese tal ilação, num ou noutro caso, no entanto, o desrespeito ao preso, representado por situações desumanas perpetradas nas prisões, faz-se repensar a pena a que estariam eles - os presos - submetidos. Se, para um fato típico e punível, há uma pena privativa de liberdade, não se pode punir o mesmo fato de outra forma, novamente, sob pena de ocorrer o bis in idem. Todavia, atualmente, para aquele que lhe foi infligido pena privativa de liberdade haverá duas punições: a primeira, a própria pena; a segunda, sua condução ao presídio para que seja objeto de humilhações e privações as quais não se apresentam dispostas na normatividade regente, e não fazem parte da própria pena privativa.

A leitura atualizada que se pode extrair da vida carcerária brasileira é a de que a pena privativa de liberdade incorpora um adendo sob a ótica da punibilidade, de modo que o preso não apenas será punido com a pena privativa, mas também sofrerá as consequências de uma reclusão ou detenção desconforme com o real sentido da pena.

Como reação natural daqueles que ficam submetidos a essa hostil realidade surge o horizonte da necessária, desmedida e única (sob o ponto de vista do apenado) oportunidade dos motins. Essa também foi a reflexão aduzida por Cezar Roberto Bitencourt (2017, p. 227), 
[...] os motins carcerários são os fatos que mais dramaticamente evidenciam as deficiências da pena privativa de liberdade. É o acontecimento que causa maior impacto e o que permite à sociedade tomar consciência, infelizmente por pouco tempo, das condições desumanas em que a vida carcerária se desenvolve.

Essa espécie totalizante de violência traz à tona a tensão existente entre a remissiva discussão sobre retributividade/restitutividade da pena. Dessa forma, paira sob o cerne da questão ponderar se a crise do sistema prisional deve ser apreciada de forma racional, de maneira a não impulsionar a sociedade cada vez mais para caracterizar a pena em seu aspecto meramente retributivo, ou seja, como castigo pelo mal cometido.

Pelo que se extrai desse contexto, seria coerente reconhecer como corolário a necessidade de o Legislativo não aderir a decisões emocionais, porquanto, racionais. No dizer de Nilo Batista (2011, p. 44), "[...] o elemento que transforma o ilícito em crime é a decisão política - o ato do legislativo - que o vincula a uma pena". $\mathrm{Na}$ verdade, não se imaginaria concepção diversa, eis que se tem como fundamento basilar o princípio da legalidade penal. Intrigante seria refletir sobre a seguinte indagação: até que ponto as penas estabelecidas são proporcionais aos delitos? Em relação a isso, é possível afirmar que a tendência generalizada pela caracterização da retributividade penal influencia o legislativo e traz consequências no incremento da pena; desrespeitando, pois, a dignidade da pessoa humana, a intervenção mínima e a proporcionalidade. Juarez Tavares (1992, p. 75), analisando o processo de elaboração das normas incriminadoras, conclui que "[...] na maioria das vezes, não há critérios para essa elaboração".

É nesse cenário descrito, cuja maior provocação advém da crise no sistema carcerário, que o estudo sobre o sentido da pena ganha relevo. A leitura perpassa pelo tratamento que essa pena tem merecido do Poder Público, principalmente no âmbito do Legislativo, no intuito de reexaminar a funcionalidade da pena privativa de liberdade. 


\section{O Poder Público frente à Crise do Sistema Prisional}

O recalcitrante tema da crise do sistema prisional já seria suficiente o bastante para que todas as esferas do poder estatal, em conjunto com os segmentos civis da sociedade, declinassem esforços convergentes no sentido de fomentar propostas concretas e exequíveis em direção à solução dos numerosos problemas que bestializam o já animalesco convívio entre os aprisionados.

Os detentos da Família do Norte fizeram pelo menos quatro vídeos com celulares mostrando os corpos de seus desafetos do Primeiro Comando da Capital (PCC) e de outras vítimas da rebelião que deixou 56 mortos no Complexo Penitenciário Anísio Jobim (Compaj), em Manaus. Com até 3 minutos de duração, os vídeos são acompanhados pela narração dos bandidos, chamando as vítimas de "nego safado" e "canalha". A maioria está com a cabeça cortada ou gravemente mutilada. As imagens da decapitação de rivais - prática que era uma das marcas do PCC - seriam uma forma de a facção demonstrar força. "Cortar as cabeças é uma forma de intimidar os inimigos e isso ficou mais fácil com as mídias sociais, com as imagens transmitidas por meio dos telefones celulares", afirmou o procurador de Justiça, Márcio Sérgio Christino, especializado no combate ao crime organizado. (MAIORIA, 2017)

A instabilidade proveniente da crise nos presídios deriva reações sucessivas com reflexos danosos na quase totalidade dos setores da sociedade. A complexidade que envolve a referida situação repugna toda e qualquer tentativa na suposta identificação de um único responsável que dispare o gatilho da geração desse fenômeno. Suposta permissividade, se aceita fosse, encarnaria a visão reducionista do problema que, repita-se, na verdade, espalha-se em decorrência de uma conjunção de diversos fatores. Vislumbra-se um verdadeiro estado pueril de análise, próprio do senso comum, a rotineira atribuição de culpa exclusiva da morosidade e ausência de comprometimento do Poder Judiciário para com a realização de uma Justiça que atenda aos interesses de pacificação e segurança da sociedade. 
Ilação necessária traduz-se no fato de que não se pode conceber a organização social de um país, concentrado oficialmente em três forças, permitindo a mera análise sob o ponto de visão, tão somente, da singularidade de reflexões e ações de apenas uma delas. Sabe-se que a tripartição estatal permite a independência dos poderes na intenção de contraporem-se à tirania, porém, atesta-se a reflexão de que, apesar de independentes, possuem uma amálgama real e necessária, pela harmonia disposta no artigo $2^{\circ}$, da Constituição Federal Brasileira de 1988.

As ponderáveis situações de ineficiência dos procedimentos havidos no Judiciário esgarçam o desgastado sentimento de justiça almejado por todos. Entretanto, não menos visíveis são as falhas ocorridas na estrutura e na atuação do Poder Executivo e do Poder Legislativo que culminam na instabilidade de segurança nos presídios. O Estado, então, transmite a sensação de não declinar esforços no sentido de programatizar políticas públicas voltadas ao tratamento de nossos problemas sociais, eis que, no particular, cabe-lhe, nos termos do artigo 144, da Constituição Federal de 1988, zelar pela segurança para a preservação da ordem pública. Sem contar o fato de que a segurança é direito fundamental do cidadão, nos termos dos artigos $5^{\circ}$ e $6^{\circ}$, caput, da Constituição Federal de 1988. Dessa forma, é inalienável a percepção de que o Estado na sua integralidade estrutural de funcionamento (Executivo, Legislativo e Judiciário) absorve, certamente, parcela razoável da culpa pela crise no sistema prisional.

Em verdadeira sintonia, e não raras as vezes, a vox populi traduz sua manifestação de encontro à atuação dos representantes parlamentares, no desempenho de suas atividades, principalmente, no tocante à realização de leis apropriadas à real situação social de nosso país. O exemplo da repreensão aos crimes hediondos é uma excelente ilustração de tal fato.

E bom lembrar-se da Lei n. 8.072, de 25 de julho de 1990, que surge entre nós com a clara intenção de prestar satisfação a setores da mídia e da população, pois que trata dos crimes hediondos, ou seja, aqueles crimes horrendos, sórdidos e sinistros, que provocam o repúdio da sociedade. O legislador, nesse caso, estabeleceu - quando da elaboração da referida Lei - no artigo $9^{\circ}$, um acréscimo da metade da pena prevista em 
determinados tipos penais (por exemplo, roubo seguido de morte, sequestro com lesão corporal grave, dentre outros), ressalvando, no entanto, que deverá ser respeitado o limite de 30 anos de reclusão. Percebe-se, então, que - naquele momento - a ideia central do legislador foi a de utilização da força na tentativa de prevenir o crime.

Nutre-se certa pacificidade no entendimento de que não é a vertiginosa e incessante escalada quantitativa ou, ainda, a rigidez da sanção que minimizará os efeitos da criminalidade, mas sim a certeza de aplicação da Lei, ou seja, a eficácia da normatividade imposta. O ponto fulcral reside em discernir o significado exaltado por eficácia da Lei. É de bom alcance o conceito representado por: nada mais que uma elaboração que atenda aos problemas sociais, uma imposição apropriada ao delito cometido, uma punição certa e uma execução proveitosa não só à sociedade como também ao condenado.

Beccaria (1993, p. 126), em sua obra clássica, é notadamente quem, com maior precisão, esclarece que a prevenção do crime não resulta da instituição cada vez maior de penas desumanas, veja-se: "Quereis prevenir os crimes? Fazei leis simples e claras [...] Não favoreçam elas nenhuma classe particular; protejam igualmente cada membro da sociedade". Observa-se, então, que a prevenção do crime é consequência de uma boa legislação.

Porém, motivado por essa definição, deriva-se o seguinte questionamento: o que seria uma boa legislação? Ainda em Beccaria (1993, p. 125), a boa legislação é aquela que "proporciona aos homens o maior bem estar possível e preservando-os de todos os sofrimentos que se lhes possam causar, segundo o cálculo dos bens e dos males desta vida".

Outro aspecto em que remanescem parcos questionamentos e dúvidas, é o fato de que a elaboração desordenada de leis remete à confusão e enfraquecimento do Direito Penal, mormente porque essa elaboração massificada dá notoriedade à intenção de atender a um Direito Penal que insiste em se impor através da força, ou seja, aquele robustecido pelas manchetes dos holofotes dos midiáticos noticiários. Nesse caso, é a justiça realizada por meios de comunicação sensacionalistas que, na grande maioria das vezes, ignora a existência do princípio da presunção de ino- 
cência, previsto no artigo $5^{\circ}$, da CF/88 - em que pese o HC 126.292/SP, julgado no STF em 17/02/2016, cujo Relator foi o Min. Teori Zavascki tenha trazido relevantes reflexões que alardearam a tese da possibilidade de flexibilização do referido princípio.

O Direito Penal acima referido, isto é, aquele realizado em virtude da "neurose" coletiva da sociedade, frente ao aumento diário da violência nas grandes cidades, possui, na grande maioria das situações, normas que não têm o necessário requinte jurídico na sua elaboração, desprovida muitas vezes do necessário tecnicismo metodológico, dos quais porejam regras confusas e contraditórias, repercutindo na provável geração de um mal ainda maior, e já tão conhecido; qual seja, a divergência entre o que a Lei diz, e o que realmente pretendia ter dito. Esse fato (equivocada redação da lei) dificulta a interpretação e a aplicação de uma justiça plena, de uma justiça pública, e que pudesse atender satisfatoriamente aos anseios de segurança da sociedade.

A justiça pública com realização plena não seria compatível, certamente, com a crise atual do sistema presidiário. Um tratamento adequado dado pelo Poder Público ao tema mobilizaria os seus diversos segmentos para alcançar um único fim; a saber, a normalização do sistema presidiário no país. Dessa forma, a atuação do Executivo e do Judiciário tem importância na medida em que se empenham em agir com a eficiência adequada no trato das questões relativas às contendas dos aprisionados. Não é de surpreender os mais incautos dos cidadãos, que há presos cuja totalidade da sua pena já fora cumprida, porém estes ainda se encontram nas dependências do cárcere, fato que acarreta consideravelmente o aumento do grau de insatisfação e revolta, fragiliza o direito daqueles e, desrespeita por completo o artigo $5^{\circ} \mathrm{LXXV}$, da $\mathrm{CF} / 88$ (que estabelece a indenização por tempo de prisão superior ao da pena).

$\mathrm{Na}$ mesma toada, a proliferada tese da morosidade do Judiciário e ausência ou insuficiente adequação procedimental dos atos consagram insólitas situações que submetem os presos ainda não condenados, mas que já se encontram nos presídios a espera de decisões judiciais. Circunstância absurda diante do diálogo ora proposto, haja vista que se o cárcere é desproporcional ao indivíduo condenado, imagine àqueles que, ainda, 
lhes resta o benefício da duvida fundamentado na presunção de inocência. Outrossim, a justiça pública demanda do Executivo a imperatividade em zelar pela integridade física e corporal do preso (art. $5^{\circ}$, XLIX, da CF/88). Sobre isso, convém registrar que as administrações dos presídios (a encargo do Executivo) muitas vezes fazem tábua rasa do mencionado inciso XLIX, do art. $5^{\circ}$, da Constituição Federal.

Noutro giro, as polícias encarregadas da segurança pública, mas que não é a regra do comportamento do seu contingente, se esquecem, por vezes, do seu verdadeiro sentido de existência (prestar segurança) e, ao desvario, passam a dar tratamento de choque e morte aos presos. O Legislativo, também, composto por representantes do povo, deve, ao elaborar as leis criminais, dispor de uma percepção compatível com o deslocamento do verdadeiro sentido da pena, do meramente retributivo para a incorporação do seu aspecto restitutivo, visando à reintegração social do condenado.

Assim, é de salutar importância, não se divorciar da conclusiva reflexão de que a justiça pública deve ser realizada pelos três poderes, pois, em sentido amplo, a justiça pública não consiste apenas no poder de julgar, mas, também, elaborar leis adequadas, bem como na forma de se cumprir aquilo que, redundantemente se julgou, ao aplicar as leis, devendo-se, pois, oportunizar aos presos, condições básicas de vida e a compatibilidade com a dignidade humana.

\section{A Pena como Castigo Estatal}

Diante do exposto é de extrema prudência perceber-se, ante a clareza da obrigação, por parte do Estado, da preservação dos direitos básicos ao homem, ainda que este seja sujeito violador das normas penais instituídas pelo mesmo Estado. No entanto, cabe indagar o porquê da existência de elementos cognitivos capazes de fomentar ânimo na concepção de que a pena deva ser tomada na forma de castigo estatal.

O termo conhecido como "pena", se realizada sua leitura de forma isolada, poderia emanar também tom de leveza - esse é o grande fenômeno do mosaico de significados herdado da nossa "Flor do Lácio" 
-, porém, nessa semântica análise, de forma mais acurada, permitindo-se lançar-se à retrovisão do tempo, à sua origem do latim, na expressão poena, com derivação do grego poine, e da origem sanscnta punia, e com isso, abrir espaço para dois significados essenciais: o primeiro, diz respeito à dor, lástima, castigo, expiação, penitência, fadiga, trabalho, ou ainda pior, sofrimento e submissão; já em sua segunda acepção, retrata-se a ideia abstrata do termo "dó" (OLIVEIRA, 2003, p. 2); a este último, porém, não se lhe reservará enquadramento como objeto de estudo das linhas deste trabalho.

A pena foi instituída ainda entre os homens que compunham os meios primários da vida em sociedade, como elemento primordial à pacificação da vida em grupo, eis que se fazia necessária não só à conservação da espécie, como também, da moral e da integridade do corpo social. Era realizada por sujeitos que, apesar de racionais, eram imbuídos de anseios e vaidades, além de forte tendência ao despotismo, cuja materialização, em detrimento dos direitos alheios, inegavelmente possibilitaria a difícil convivência diária. $\mathrm{O}$ escopo da referida definição encontra respaldo, portanto, na ideia central dos iluministas que resenharam a pena como elemento mantenedor da ideia de grupo na sociedade. Até mesmo porque, como afirma Beccaria (1993, p. 25), o homem, uma vez cansado de defender sua vida, sua família e seus pertences, sozinho, renuncia parcela de sua liberdade na intenção de viver em uma sociedade que lhe transmitisse segurança, embora o impossibilita-se da realização de uma liberdade plena.

Nessa investida reflexão, com foco na linha do tempo pretérita, vem à tona a lembrança de que os crimes muitas vezes confundiam-se com $\mathrm{o}$ pecado. A título de exemplo tem-se a obra denominada "o Livro Quinto" que relatava como primeiro e mais importante crime, o da heresia. O comentário enaltece a visível confusão da ideia de religião e Estado, pois, como de notório e público saber, a pena de outrora era o castigo pelo mal (pecado) cometido (SOUZA, 1999, p. 6).

Tempos depois, passou a pena a ser entendida como sendo a realização da justiça, ou seja, retribuir ao autor do delito um mal. E que mal seria esse? A resposta a essa indagação seria mais apropriadamente, a pena, que, ainda assim, continuava representando um castigo. Esse enten- 
dimento permaneceu até a transição do Estado Absolutista para o Estado Liberal, que, com base nas ideias iluministas, fizeram surgir as teorias relativas da pena, as quais outorgaram a esta, a manutenção da sobrevivência do grupo. Frise-se que Michel Foucault (1987, p. 54) revelou que o principal objetivo daquela época era, antes de tudo, estabelecer uma proporcionalidade do castigo ao delito cometido.

Não seria de todo impróprio observar que houve na sociedade moderna uma inversão de valores, pois como se tem notícias, os suplícios entre os povos primitivos eram suplementos antecedentes às penas de morte, isto é, prestavam-se tão somente para os crimes considerados graves e bárbaros, pois causava efeito amedrontador (OLIVEIRA, 2003, p. 29). A partir do século XVIII, os protestos contra os suplícios tornaram-se rotina entre juristas, magistrados, parlamentares, filósofos, legisladores e técnicos do Direito. Houve uma tentativa de humanização da pena.

Foucault (1987, p. 70) relatou, ainda, que a necessidade de um castigo sem suplícios vem, inicialmente, formulada "[...] como um grito do coração ou da natureza indignada: no pior dos assassinos, uma coisa pelo menos deve ser respeitada quando punimos: sua humanidade". O homem passava, então, a ser a medida do poder. Também, sobre o assunto, já afirmara Seligman (1983, p. 13-20, apud FOUCAULT, 1987, p. 69):

Que as penas sejam moderadas e proporcionais aos delitos, que a morte só seja imputada contra os culpados assassinos e sejam abolidos os suplícios que revoltem a humanidade.

Seguiu-se, então, à mudança de formato que deu azo à redução da pena de morte, bem como dos suplícios. Na atualidade, a referida tese encontra-se abraçada pelo Brasil na sua Carta Magna. A atual Constituição Federal estabelece, no artigo $5^{\circ}$, XLVII, alínea "a", como cláusula pétrea, a vedação da pena de morte (podendo apenas ser admitida em caso de guerra, nos termos do art. 84, XIX). A Lei Maior brasileira também expressamente vedou os suplícios, conforme estatui o artigo $5^{\circ}$, XLVII, alínea "e". 
Cumpre lembrar que ainda remanesce a aplicação de suplícios na contemporaneidade, apesar de provocar a repulsa social dessa prática. É bem verdade que o referido ato não guarda a pungência reservada à conotação de outrora, até mesmo porque o espetáculo da punição física desaparece no início do século XIX. Hoje, o suplício está configurado na forma de punição da personalidade individual do homem encarcerado, ganhando contornos hostis quando da humilhação constante e da insistente pressão psicológica da necessidade de manter-se vivo, revelando um sistema em que as regras favorecem os mais fortes e banalizam os mais fracos. É nesse sentido que a vida, antes valorada, encontra-se em vertiginoso descrédito, motivando a sociedade, de maneira infeliz, a ideia da pena de morte como tentativa de combate a uma violenta e organizada criminalidade.

Não seria desarrazoado inclinar-se ao ideal de que deve ter a pena a função de zelar pela convivência pacífica dos homens organizados em sociedade, prescindindo-lhe o selo conotativo de castigo, retribuição do mal cometido, intimidação ou de segregação do indivíduo da sociedade, pois que é dever do "remédio social" prescrever ao homem que transgride a norma penal estabelecida, não o simples castigo, mas a recuperação, a reeducação para que não reitere a realização de delitos. Entendendo ser necessário nortear a vida dos homens para a realização constante do bem, não se pode, então, praticar o mal. Mas que mal seria esse? Não é outro, senão, o desprezo daquele que opta pelo mal.

Nas possíveis vertentes do comportamento humano, especificamente ao que tange à opção de escolha do exercício e prática do mal, insere-se aquele homem de natureza comportamental amoral. Melhor dizendo, aquele ser humano desprovido das amarras do conceito entre o bem e mal, que não tonifica seu comportamento baseado nessa dicotomia e, portanto, não bifurca suas ações na escolha de qual caminho seguir por esses paradigmas. A este - ao contrário daquele -, que não distingue tal valoração típica e, portanto, isento de qualquer sentimento; necessita, então, de um amparo ainda maior à realização do bem. E que amparo seria esse? Reclama-se aqui a aceitação de que não poderia ser outro senão a pena, que deve ter como principal intenção amoldar-se como pedra angular da nova vida do indivíduo cometedor de determinado delito. Mas 
aquela pena deve, antes de tudo, basear-se em princípios éticos, procurar, antes de qualquer coisa, restaurar, educar e amparar o indivíduo para a não realização de crimes, tomando-se, assim, valorativa, justa e eficiente.

A pena, também, não deve atingir direitos inalienáveis para todo homem (aqueles garantidos no artigo $5^{\circ}, \mathrm{CF} / 88$ ). São exemplos, entre outros, o princípio da personalidade, ${ }^{1}$ o da proporcionalidade, etc. A esse respeito, faz-se necessário lembrar que o princípio da proporcionalidade ${ }^{2}$ está em nosso Direito positivo, notadamente no artigo $5^{\circ}, \mathrm{XLVI}, \mathrm{CF} / 88$, ao determinar que a "lei regulará a individualização da pena". Ainda, no Código Penal, artigo 59, observa-se que não só a culpabilidade deve ser analisada quando da aplicação da pena, mas também, os antecedentes, a conduta social, a personalidade do agente e as consequências do crime, bem como, no artigo 61, I, do CPB, ressai a reincidência como circunstância que pode agravar a pena. Todos esses elementos, conjuntamente apreciados quando da aplicação da pena, eleva o sentimento real a ela destinado, no sentido de que se revele proporcional ao delito cometido.

Ainda que não haja um entendimento uníssono sobre os resultados projetados, e que se mantenha discurso a rechaçar o alto investimento no interesse social de restauração do indivíduo, pela tentativa de preservação e valoração de seu autoconceito, de sua identidade; tal preocupação, ainda que legítima, não deve inclinar-se, tão somente, pelo aporte financeiro e público que será empregado, eis que a projeção do retorno social superaria o numerário aplicado, vez que resgataria o indivíduo, também na sua qualidade de homem produtivo.

Noutro giro, aplicando-lhe diversa concepção, associar a pena à pecha de castigo ensejaria a possibilidade vinculada de um mal irreversível e seus reflexos derivariam em traumas sociais, com nefastos efeitos a toda

\footnotetext{
${ }^{1}$ Art. $5^{\circ}$ XLV, primeira parte da CFB. "Nenhuma pena passará da pessoa do condenado". ${ }^{2}$ Sobre o princípio da proporcionalidade, Juarez Tavares (1992, p. 84) afirma o que se segue: “[...] concebida como expressão do poder, a pena, contudo, deve guardar uma relação proporcional com o dano social produzido pelo delito. Desde que inexista essa relação ou se apresente ela de modo absolutamente inexpressiva, pode-se questionar a validade da norma que instituiu a punição, em face de haver o legislador atuado arbitrariamente na sua confecção".
} 
comunidade. Enfim, males que são refletidos na sociedade cujos desdobramentos tendem a delongar-se a médio e longo prazo.

Destarte, aparelha-se muito mais promissor e arrazoado com o Estado de Direito Social conceber como principal intenção da pena a humanização do indivíduo transgressor. Afasta-se, portanto, do plano da razoabilidade, que a finalidade da pena tenha caráter retributivo, por uma razão muito simples: o caráter retributivo não humaniza. Ele seria, então, mais apropriado para aquelas penas em que os infratores não são reintegrados na sociedade, a exemplo da pena de morte e perpétua (inadmitidas em nosso Direito Constitucional, salvo a primeira, apenas em caso de guerra). Nesses dois casos, ao que tudo indica, a finalidade é realmente retributiva. Já em relação aos outros casos, a restitutividade é condição elementar para proporcionar a prevalência do convívio harmônico na sociedade e sua apreensão passa pela reflexão da pena de prisão.

\section{O Cárcere e a sua Identificação com a Pena}

A taxa de aprisionamento de pessoas no Brasil nas últimas décadas, em relação à sua população absoluta, atingiu níveis alarmantes. A "superlotação carcerária" põe em xeque a essência do sistema prisional, a demanda legislativa criminal e a sua inerente procedimentalização. É grotesco, porém real, o cenário de aprimoramento da criminalidade que é alcançado no interior do cárcere, fazendo com que a sofisticada engrenagem idealizada pelo crime organizado seja paradoxalmente forjada pelo próprio sistema estatal, criado para debelá-lo.

Em junho de 2016 a população prisional brasileira ultrapassou, pela primeira vez na história, a marca de 700 mil pessoas privadas de liberdade, o que representa um aumento da ordem de 707\% em relação total registrado no início da década de 90. (INFOPEN, 2017, p. 9)

Sobeja de forte coerência os esclarecimentos de Bitencourt (2017, p. 168) acerca do inquestionável aumento da delinquência em toda a América Latina, notadamente, quando traz à tona uma reflexão sobre a 
realidade violenta e opressiva do sistema penitenciário tradicional que, por sua vez, serve, tão somente, para reforçar os valores negativos dos condenados.

Para declinar realce em suposta classificação daqueles que envidam esforços ao estudo do tema, poder-se-ia dividi-la entre cautelosos e idealistas, segundo José Arthur Rios (1995, p. 37). Os primeiros acreditam na necessidade de uma investigação cautelosa de quais crimes podem receber penas a serem cumpridas no meio livre, possibilitando, então, uma redução das penas prisionais, uma vez que pretendem atribuir àquelas um intuito pedagógico, terapêutico e recuperador. Já os idealistas "clamam por um novo Beccaria" e acreditam que a meta a se alcançar é a extinção total da prisão, "com a derrubada de seus muros, fato este anunciado por setores mais radicais como uma nova queda da Bastilha".

À vista desse introito, a atitude do aprisionamento recairia então como a derradeira das soluções. Entretanto, paira um incômodo questionamento: seria mesmo a extinção total dessa instituição realmente a maneira mais eficaz para a realização de uma justiça plena? $\mathrm{Na}$ esfera do Direito Penal, ante a própria natureza da substância do bem tutelado, reclama-se, com intenso vigor, um comportamento deveras cauteloso, pois a interpretação desprovida de profunda e sistemática reflexão acerca dos consequentes desdobramentos, inevitavelmente demandaria a subtração de um aquilatado bem da vida imanente a todo ser humano: a liberdade. Portanto, aquele comando que vai decidir uma vida, não pode prescindir de escrupulosa e aperfeiçoada observação minuciosa de fatos, no esforço de alcançar uma solução, não só formalmente perfeita, sobretudo eficaz, ou seja, é o passo a passo de uma realização constante da prevenção.

Já faz parte da consciência coletiva e também de reflexões balizadas que o encarceramento pela prisão não consegue traduzir a real finalidade da pena, e que a contrario sensu, não se presta a desfazer um crime já cometido, posto que tal desiderato estaria situado fora do plano da possibilidade.

A prisão, cujos primórdios remontam aproximadamente meados do século V, inicialmente foi aplicada tão somente nos mosteiros, aos monges ou clérigos que, pelo acometimento de algum erro, infligiam-lhes o 
recolhimento a celas individuais, submetidos à solidão e ao silêncio, para que se dedicassem exclusivamente à meditação, na tentativa do arrependimento da alma e de uma reconciliação com Deus (PIMENTEL, 1983, p. 134). Era o resgate do pecado pela dor. No entanto, fato não muito explorado e divulgado recaia sobre a ocorrência de constantes suicídios.

É de brutal esforço - quiçá pela impossibilidade - a inglória tarefa cuja finalidade seja a de restaurar e ressocializar alguém que conviveu (ainda que por curto espaço de tempo) perante uma situação adversa de valores e ideais daqueles que estão na sociedade liberta e, ainda, fazê-lo sentir-se igual àqueles que sempre estiveram libertos, simultaneamente à sua prisão. A mercê de tal reflexão, é possível que se apresentem duas conclusões contrárias. A primeira é a que admite a impossibilidade de conciliação entre os valores que o preso vivenciou dentro do presídio e aqueles que, após liberto, passará a vivenciar fora do presídio. Nesse caso, já que o preso nunca iria readquirir os valores da sociedade livre, a pena realmente só poderia ser justificada como um castigo, já que a ressocialização seria impossível. A outra seria reconhecer a realidade da divergência de valores intra e extrapresídio: admite a impossibilidade de conciliação desses valores quando da libertação do preso e, com base nessas constatações, tenta mudar a realidade, fazendo com que os valores extrapresídio passem a ser valores intrapresídio, de forma a reeducar e ressocializar o preso.

Considerando que as instituições totais são simbolizadas pelo fechamento para o mundo exterior (fechamento realizado pelos elementos físicos da instituição), sua força consiste no poder que tem de esfacelar a família. Em nossa sociedade, as instituições totais são uma espécie de laboratório pessoal, onde o principal experimento é a desconstrução da identidade individual (GOOFMAN, 1961, p. 16-17). Dessa forma, quando um aprisionado permanece por um tempo consideravelmente longo, essa estada pode ocasionar uma incapacidade temporária para a realização de sua vida diária em liberdade, pois as instituições totais dificultam a socialização dos indivíduos.

A pena privativa de liberdade apresenta diversas dificuldades, a saber, o custo da construção das instituições e a manutenção destes estabele- 
cimentos, além do gasto com o indivíduo preso. A expressão numérica do alto custo de um aprisionado foi enfatizada pela Ministra Cármen Lúcia:

Um preso no Brasil custa $\mathrm{R} \$ 2,4$ mil por mês e um estudante do ensino médio custa $\mathrm{R} \$ 2,2$ mil por ano. Alguma coisa está errada na nossa Pátria amada. A constatação foi feita pela presidente do Supremo Tribunal Federal (STF) e do Conselho Nacional de Justiça (CNJ), ministra Cármen Lúcia, que participou nesta quinta-feira (10/11) do $4^{\circ}$ Encontro do Pacto Integrador de Segurança Pública Interestadual e da $64^{\text {a }}$ Reunião do Colégio Nacional de Secretários de Segurança Pública (Consesp), em Goiânia/GO. (AGÊNCIA CNJ, 2017)

No entanto, são custos materiais que, se fossem aplicados de acordo com o seu real objetivo, qual seja, a recuperação e sociabilização do indivíduo transgressor, estariam sendo destinados a uma causa justa; portanto, de per si, justificáveis.

A maior dificuldade da pena privativa de liberdade, no entanto, encontra-se na convivência dos infratores primários com transgressores reincidentes, assim como aqueles que ficam no aguardo de julgamento. Muitas dessas dificuldades estão dispostas na exposição de motivos da Lei n. 7.209, Código Penal. No entanto, nem mesmo diante de tantas dificuldades, não se pode descurar-se da realidade à negativa de que a prisão é, como de fato se apresenta, talvez a única forma da qual a sociedade dispõe atualmente para lidar com os transgressores classificados como sendo de alta periculosidade. Até mesmo os estudiosos mais críticos do sistema prisional, quando questionados sobre qual solução dar a esses transgressores, afirmam que, apesar de demonstrar tantos problemas, a prisão ainda é a única solução disponível.

Zaffaroni (2012, p. 135-136) talvez seja quem melhor define a prisão, quando relata que

[...] a prisão ou cadeia é uma instituição que se comporta como uma verdadeira máquina deteriorante: gera uma patologia cuja principal característica é a repressão. A prisão não deteriora por deteriorar, mas o faz para condicionar: invade o indivíduo com suas exigên- 
cias do papel que também lhe são formuladas pelas outras agências do sistema. Trata-se de uma verdadeira lavagem cerebral, da qual fazem parte, inclusive, os demais prisioneiros que interagem com aquele submetido ao tratamento criminalizante.

Goffman (1961, p. 22.) acrescenta que não só a prisão, mas também as instituições totais de maneira geral, “[...] em nossa sociedade, são estufas para mudar pessoas; cada uma é um experimento natural sobre o que se pode fazer ao eu".

Percebe-se, então, que a prisão promove, através da força, o desenvolvimento de padrões de comportamento e de crenças diversos do mundo exterior, até mesmo porque são criados, na maioria das vezes, na intenção de preservar a sua integridade e, apesar dessas normas serem típicas de uma sociedade, não desenvolvida culturalmente, são cumpridas com extremo rigor, por isso a prisão deve ser reservada apenas aos que representam gravíssimos riscos à sociedade.

Como já se disse anteriormente, as penas privativas de liberdade apresentam inúmeras dificuldades, mas a dificuldade mais polêmica é a violação constante, aos direitos humanos, em que a vida humana não passa de uma mera balela. É a partir dessa dificuldade e da consciência coletiva de que a longa duração das penas privativas de liberdade em nada reprimem a criminalidade, que se tem pensado e abordado cada vez mais na necessidade de um uso menor das penas privativas de liberdade, sendo estas substituídas pelas penas alternativas.

A pena alternativa é uma pena restritiva de direitos, aplicada a quem pratica crime sem violência ou grave ameaça e não possui antecedentes criminais ou tenha aplicada pena privativa de liberdade não superior a quatro anos. Não pode ser aplicada em caso de réu reincidente, a menos que seja "socialmente recomendável" e que a reincidência "não tenha se operado em virtude da prática do mesmo crime" ( $\S 3^{\circ}$, do art. 44, do Código Penal).

As penas restritivas de direitos encontram-se classificadas no artigo 43, do CPB, com a redação da Lei n. 9.714/98. A promoção dessa sanção encontra fundamento na necessidade de humanização das penas, toman- 
do-as mais justas e proporcionais aos delitos cometidos, o que por sua vez, permite maior individualização da pena e, ainda, a possibilidade real da diminuição da reincidência, pois livra o indivíduo dos efeitos negativos do cárcere.

Observa-se, ainda, como vantagens da pena alternativa, a diminuição de custos para o Estado, pois diminui a população carcerária e obriga o indivíduo cometedor de delito ao trabalho voluntário em entidades filantrópicas. No entanto, faz-se necessário lembrar que a aplicação de penas alternativas deve ser fruto de muita pesquisa e maturação, pois pode causar na sociedade a ideia de falta de condenação, de fiscalização ou, ainda, de que a lei, assim como sua aplicação, está favorecendo a realização de delitos e aumento da criminalidade.

Diante do todo exposto, acredita-se que o maior estímulo de nosso século deve ser a convocação dos setores da sociedade civil organizada para a realização de uma nova identidade social e moral, na tentativa de materializar uma política criminal mais justa. Esta, por sua vez, deve ser instituída através de práticas que tenham como fundamento primordial o respeito à dignidade humana e a promoção de um efetivo desenvolvimento da cidadania. Só a partir da consciência e do respeito a esses direitos (básicos à vida do homem na sociedade), é que se torna possível atribuir à pena o sentido de educação, visto que não mais haverá a necessidade de repressão, de castigo, pois o homem convicto de seu papel na sociedade erra por um deslize, por isso não deve ser castigado.

Pois bem, não se pode negar que o momento - que não é atual -, é de instituição de uma nova cultura e, melhor seria aquela, senão a que defende a humanização da pena privativa de liberdade fundamentada na garantia dos direitos humanos.

\section{Conclusão}

Já na década de 1990, César Barros Leal (jul./dez. 1993, p. 136) relata a falência do sistema prisional brasileiro quando admite que é factível que a sociedade adquira a capacidade de indignação não apenas em face do crime, mas, também, diante do abandono das prisões, e que não silen- 
cie diante da infâmia e da barbárie. Se é possível extrair algo de positivo advindo da crise do sistema prisional, este se faz ante a análise de determinados momentos, em que a sociedade repensa o real sentido da pena. Como diz Bitencourt (2017, p. 227),

[...] o motim, uma erupção de violência e agressividade, que comove os cidadãos, serve para lembrar a comunidade que o encarceramento do delinquente posterga o problema. Ele rompe o muro de silêncio que a sociedade levanta ao redor do cárcere.

Observa-se, ainda, que esse muro não é levantado apenas pelos leigos, mas, como afirma Leal (1993, p. 136):

[...] concorrem para a ultrajante realidade de nossos presídios a incúria do governo, a lentidão da justiça e a apatia do Ministério Público e de todos os órgãos incumbidos de exercer uma função fiscalizadora, por atribuição legal, mas que, no entanto, em face de sua omissão, tornam-se cúmplices do caos.

Nesse contexto, entende-se que a tensão existente entre a finalidade retributiva e restitutiva do cárcere pode ser desvendada com o estudo evolutivo das penas. Atualmente, não mais se admite a pena com função primordialmente retributiva. Porém, há elementos objetivos que impedem a caracterização exclusiva da restitutividade penal. Basta ver o que reza o artigo $5^{\circ}$, LIX, da CF/88 (será admitida ação privada nos crimes de ação pública, se esta não for intentada no prazo legal). Assim, torna-se possível observar que, o particular, autorizado pela Constituição, pode ingressar com a ação privada em substituição da pública (ação penal privada subsidiária da pública). Ora, não tem ele (o particular), logicamente, a intenção de ver o infrator condenado para que seja reeducado. Naturalmente, o particular encontra-se impulsionado pela repulsa e indignação em relação ao crime cometido, desejando, notadamente, o castigo ao réu. Tal argumento, extraído do próprio ordenamento positivo, faz-se concluir que a pena realmente possui certo caráter de retributividade. Mas, esse caráter não deve ser tomado como o predominante, até mesmo porque a própria 
Constituição Federal não admite possibilidade de pena de morte e perpétua, provando, então, a sua repulsa pela mera retributividade penal.

Nessa linha de raciocínio, os presídios manifestam-se, atualmente, como instrumentos inadequados à recuperação do autoconceito do indivíduo, fazendo parecer que a sua subsistência atende às finalidades de retribuição do mal cometido pelo infrator. $\mathrm{O}$ perigo em se ter a retributividade como luz a iluminar a ação do Poder Público no manejo com o crime termina por gerar legislações desproporcionais e situações desumanas perpetradas nos presídios. Deve-se ter a consciência de que o trânsito em julgado da ação penal condenatória (art. $5^{\circ}, \mathrm{LVII}, \mathrm{CF} / 88$ ) não pode ser encarado como a finalização dos trabalhos, através da qual a sociedade se sente saciada com a realização de "justiça".

O episódico momento processual deve ser apreendido como ponto inicial de um árduo trabalho de revalorização e reeducação de um membro da sociedade. Essa consciência merece ser valorizada pelo Poder Público (Executivo, Legislativo e Judiciário), a fim de implementar não apenas a justeza da sociedade mas também a vontade da Constituição, que expressamente se subordinou à tendência universal de defesa dos direitos humanos, inclusive dos presos.

\section{Referências}

\section{AGÊNCIA CNJ DE NOTÍCIAS. Carmen Lúcia diz que preso custa} 13 vezes mais do que um estudante no Brasil. [2017]. Disponível em: http://www.cnj.jus.br/noticias/cnj/83819-carmen-lucia-diz-que-presocusta-13-vezes-mais-do-que-um-estudante-no-brasil. Acesso em: 4 jun. 2017.

BATISTA, Nilo. Introdução Crítica ao Direito Penal Brasileiro. 12. ed. Rio de Janeiro: Renavan, 2011.

BITENCOURT, Cezar Roberto. Falência da Pena de Prisão: causas e alternativas. 5. ed. São Paulo: Saraiva, 2017.

BECCARIA, Cesare. Dos Delitos e Das Penas. Rio de Janeiro: Ediouro, 1993. 
FOUCAUlT, Michel. Vigiar e Punir: Nascimento da Prisão. Petrópolis: vozes, 1987.

GAYA, Soraya Taveira. Direitos Humanos X Motim De Presos. [2017]. Disponível em: http://uj.novaprolink.com.br/doutrina/3911/direitos humanos_x_motim_de_presos. Acesso em: 31 jan. 2017.

GOFFMAN, Erving. Manicômios, Prisões e Conventos. São Paulo: Perspectivas, 1961.

INFOPEN - Levantamento Nacional de Informações Penitenciárias (Atualização). Organização: Thandara Santos. Colaboração: Marlene Inês da Rosa [et al.]. Brasília: Ministério da Justiça e Segurança Pública. Departamento Penitenciário Nacional, 2017.

LEAL, César Barros. A Realidade prisional e os direitos do encarcerado no Brasil. Arquivos do Ministério da Justiça, Brasília: Ministério da Justiça, jul./dez. de 1993.

MAIORIA dos detentos de rebelião em Manaus foi decapitada pela Família do Norte. O Dia, [S.l.], 4 de janeiro de 2017. Disponível em: http://odia.ig.com.br/brasil/2017-01-04/maioria-dos-detentos-de-rebeliaoem-manaus-foi-decapitada-pela-familia -do-norte.html. Acesso em: 2 jan. 2019 .

OLIVEIRA, Odete Maria de. Prisão: um paradoxo social. 3. ed. Florianópolis: EdUFSC; Assembleia Legislativa do Estado de Santa Catarina, 2003.

PIMENTEL, Manoel Pedro. O Crime e a Pena na Atualidade. São Paulo: RT, 1983.

RIOS, José Arthur. O Paradoxo da Penitenciária. Carta Mensal (discurso proferido em 1995). Rio de Janeiro: Confederação Nacional do Comércio, Conselho Técnico.

SOUZA, Carlos Fernando Mathias de. Os Crimes nas Ordenações. Jornal Correio Braziliense, [S.l.], Caderno Direito \& Justiça, 22 de novembro de 1999.

TAVARES, Juarez. Critérios de Seleção de Crimes e Cominação de Penas. Revista Brasileira de Ciências Criminais, número especial, dezembro de 1992,. 


\begin{abstract}
ZAFFARONI, Eugênio Raul. Em Busca das Penas Perdidas. Rio de Janeiro: Renavan, 2012.
\end{abstract}

Vanessa Alexsandra de Melo Pedroso é Pós-doutora pelo Programa de Pesquisa em Ciências sociais, Crianças e Adolescentes na América Latina da rede: PUCSão Paulo (BR) e Centro Latino Americano de Ciências Sociais (CLACSO). Doutora em Direito Penal pela Universidad Complutense de Madrid (España), onde investigou o crime de Tráfico de Seres Humanos e a interferência do marco no Código Penal Espanhol de 1995 para a prevenção de referido delito no âmbito da União Européia. Diplomada em Estudos Avançados (DEA) pela mesma Universidade e especialista em Relações Internacionais na era da Globalização pela Universidade Católica de Pernambuco (Brasil). Atualmente é Professora de Direito Penal da Universidade Católica de Pernambuco, onde, também, leciona, na condição de Professora Permanente, em seu Programa de Pós-Graduação em Direito (Mestrado e Doutorado). É, também, líder do grupo de pesquisa Direitos Fundamentais: Instrumentos de concretização (Plataforma Lattes). Tem experiência na área de Direito, com ênfase em Direito Público, atuando principalmente nos seguintes temas: movimento migratório - com atenção ao fenômeno da feminização da imigração, tráfico internacional de seres humanos e imigração ilegal, exploração sexual e prostituição - futuro do Direito Penal e Direito Penal da globalização.

E-mail: vanessampedroso@gmail.com

Endereço profissional: Rua do Príncipe, n. 526, Boa Vista, Recife, PE. CEP: 50050-900.

Carlos Jair de Oliveira Jardim é mestrando em Direito pela Universidade Católica de Pernambuco, na área de concentração em Direito, Processo e Cidadania, em que investigou o tema - As sentenças judiciais e o sistema normativo recursal: desconstrução dos conceitos de juridicidade e legalidade à luz do princípio da eficiência; sob a orientação do professor doutor João Paulo Fernandes de Souza Allain Teixeira. Graduação em Direito pela Universidade Católica de Pernambuco. Especialização pela Universidade de Pernambuco. 
Graduação em Ciência da Computação pela Universidade Católica de Pernambuco. Professor da Universidade Católica de Pernambuco (UNICAP), desde 2017; e

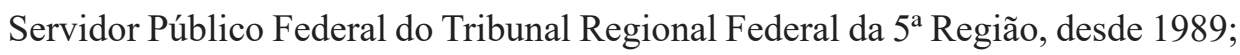
atualmente, exerce suas funções no Gabinete do Desembargador Federal Cid Marconi.

E-mail: jair.jardim@gmail.com

Endereço profissional: Rua do Príncipe, n. 526, Boa Vista, Recife, PE. CEP: 50050-900. 